\title{
ANALISIS EFISIENSI PEMASARAN RUMPUT LAUT (Eucheuma cottonii) DI KOTA TUAL PROVINSI MALUKU
}

\author{
Sahibul Khafi Hamid \\ Staf Pengajar Politeknik Perikanan Negeri Tual, $\boldsymbol{e}$-mail: -
}

\begin{abstract}
ABSTRAK
Penelitian ini bertujuan untuk; 1). Mengetahui bentuk struktur pasar rumput laut (Eucheuma cottonii) kering di kota Tual; 2). Mengetahui perilaku pasar rumput laut (Euchema cottonii) kering di kota Tual; 3). Mengetahui penampilan pasar rumput laut (Eucheuma cottonii) kering di kota Tual. Metode analisis yang digunakan adalah; 1). Analisis struktur pasar meliputi, hambatan keluar masuk pasar, pengetahuan pasar, pangsa pasar dan konsentrasi pasar; 2). Analisis perilaku pasar meliputi, proses penjualan dan pembelian, sistem pembayaran serta kerjasama; dan 3). Analisis penampilan pasar meliputi, marjin pemasaran, analisis bagian harga yang diterima petani, analisis rasio keuntungan dan biaya pemasaran. Hasil penelitian menunjukan adanya 3 pola saluran pemasaran, struktur pasar ditingkat pedagang pengumpul hingga pedagang besar antar pulau bersifat oligopsoni (banyak penjual, sedikit pembeli), posisi tawar petani rumput laut yang rendah sebagai akibat dari adanya ikatan yang kuat dengan pedagang pengumpul yang menjadi langganan tetapnya, dalam hal ini berupa pinjaman modal dan pinjaman biaya hidup sehari-hari, sehingga mengakibatkan petani rumput laut cenderung sebagai penerima harga, hambatan masuk pasar cukup besar. Berdasarkan hasil analisis tersebut diperoleh bahwa semakin banyak jumlah pelaku pemasaran yang terlibat dapat mengakibatkan marjin menjadi lebih besar, marjin pemasaran dari petani hingga pedagang besar antar pulau Rp. 5.540/kg. Petani rumput laut membutuhkan suatu wadah baik dalam bentuk koperasi atau organisasi lain sebagai tempat berkumpul dalam menjalankan kegiatan usaha budidaya rumput laut, sehingga mereka dapat mengatasi permasalahan secara bersama, baik itu input, teknik produksi, pemasaran maupun informasi pasar.
\end{abstract}

\section{Kata Kunci: Rumput Laut, Efisiensi, Struktur, Perilaku, Penampilan pasar}

\section{PENDAHULUAN}

\subsection{Latar Belakang}

Dalam menghadapi peluang dan tantangan pembangunan dalam era globalisasi, maka pembangunan perikanan serta pengelolaan sumberdaya pesisir harus mampu mentransformasikan berbagai usaha perikanan masyarakat ke arah bisnis dan swasembada secara menyeluruh dan terpadu.

Provinsi Maluku merupakan Provinsi Kepulauan dengan luas wilayah $712.480 \mathrm{~km}^{2}$, terdiri dari 92,4 \% luas perairan $\left(658.295 \mathrm{~km}^{2}\right)$ dan 7,6 \% luas daratan $\left(54.185 \mathrm{~km}^{2}\right)$. Dari 1430 buah pulau di Provinsi Maluku, secara fisik terdapat potensi panjang garis pantai 11.098,34 $\mathrm{Km}$. Potensi sumberdaya perikanan yang terkandung dalam wilayah perairan Nasional dan
Zona Ekonomi Eksklusif Indonesia (ZEEI) seluas 5,8 juta $\mathrm{Km}^{2}$ adalah sebesar 6,26 juta ton/tahun, dari jumlah ini sekitar 26,3\% berada di perairan Maluku dan menyebar pada beberapa laut potensial seperti Laut Banda, sebesar 240.948 ton/tahun, Laut Seram sebesar 45.199 ton/tahun, dan Laut Arafura sebesar 171.093,6 ton/tahun (Nikijuluw et al, 2007). Dari gambaran tersebut telah menunjukan bahwa wilayah perairan Maluku memiliki potensi perikanan yang sangat besar jika dibandingkan dengan daerah lain di Indonesia, sehingga dapat dijadikan modal dasar pembangunan daerah sekaligus sumber utama kesejahteraan masyarakat.

Salah satu komoditi sumberdaya pesisir yang ekonomis adalah rumput laut. Dari ratusan jenis rumput laut yang tersebar di perairan pantai 
Indonesia, terdapat 4 jenis bernilai ekonomis yaitu marga Gracilaria, Gelidium dan Gelidiella sebagai penghasil agar, dan marga Hypnea serta Eucheuma sebagai penghasil carrageenan. Usaha pembudidayaan ini dapat dikerjakan para nelayan/petani rumput laut dengan memanfaatkan tenaga kerja keluarga. Menurut Suhendar (2006) prospek agribisnis rumput laut ini masih sangat menjanjikan baik bagi petani yang membudidayakan maupun industri pengolah rumput laut.

Komoditas rumput laut merupakan salah satu komoditas yang masuk dalam program revitalisasi perikanan. Dua alasan penting rumput laut tersebut menjadi pilihan, pertama, pasar produk derivatif dalam bentuk food grade dan nonfood grade sangat bervariasi dan permintaan pasar dunia terhadap produk ini cukup tinggi (Anggadiredja, 2007) kedua, penguasaan teknologi budidaya (sistem rakit atau long line) mudah diadopsi oleh pembudidaya (Sukadi, 2007).

Kota Tual merupakan daerah kepulauan yang terletak di provinsi Maluku, dimana memiliki potensi sumberdaya pesisir yang cukup besar, salah satu sumberdaya pesisir kota Tual adalah budidaya rumput laut serta adanya intervensi pemerintah daerah untuk mengembangkan industri rumput laut di daerah ini cukup besar.

Pemasaran dapat diartikan sebagal runtutan kegiatan atau jasa untuk memindahkan suatu produk dari titik produsen ke titik konsumen. Komponennya adalah: a) Kegiatan yang disebut jasa merupakan fungsi yang merubah produk berdasarkan bentuk, waktu, tempat atau kepemilikan; b) Produsen adalah asal produk dijual pertama yakni petani; c) Konsumen merupakan tujuan akhir dalam transaksi pasar (Anindita, 2003).

Dalam sistem pemasaran hasil perikanan, terdapat conflict of interest dari tiga pilar utama yaitu produsen yang menginginkan harga yang tinggi, sementara konsumen menghendaki harga yang murah dan lembaga pemasaran yang menghendaki keuntungan maksimal. Persoalannya kemudian bahwa dalam pemasaran komoditi perikanan, studi empiris menunjukkan bahwa pihak yang paling banyak dirugikan adalah petani, sedangkan pedagang pada umumnya memperoleh keuntungan yang lebih besar atau dengan kata lain sistem pasar masih jauh dari prinsip keadilan.

Efisiensi pemasaran merupakan pangkal pokok dari tujuan yang ingin dicapai dalam setiap sistem pemasaran hasil perikanan. Secara umum, suatu sistem pemasaran dikatakan efisien apabila mampu menyampaikan produk dari tingkat petani produsen ke tangan konsumen akhir dengan cara memuaskan kepentingan semua steakholders dalam pemasaran secara adil sesuai dengan tingkat pengorbanannya masing-masing.

Dari uraian tersebut maka merupakan hal yang sangat penting untuk melakukan kajian terhadap sejauh mana tingkat efisiensi pemasaran rumput laut (Euchema cottonii) kering di kota Tual.

\subsection{Perumusan Masalah}

Berdasarkan latar belakang tersebut, maka permasalahan dalam penelitian ini dapat dirumuskan sebagai berikut :

1. Bagaimana struktur pasar rumput laut (Eucheuma cottonii) kering di kota Tual?

2. Sejauh mana perilaku pasar rumput laut (Euchema cottonii) kering di kota Tual?

3. Bagaimana penampilan pasar rumput laut (Eucheuma cottonii) kering di kota Tual?

\subsection{Tujuan Penelitian}

Berdasarkan rumusan masalah, maka penelitian ini bertujuan :

1. Mengetahui struktur pasar rumput laut (Eucheuma cottonii) kering di kota Tual.

2. Mengetahui perilaku pasar rumput laut (Euchema cottonii) kering di kota Tual.

3. Mengetahui penampilan pasar rumput laut (Eucheuma cottonii) kering di kota Tual.

\subsection{Kegunaan Penelitian}

Berdasarkan penelitian ini, kegunaan penelitian adalah:

1. Penelitian ini diharapkan memberikan pertimbangan dalam perbaikan sistem pemasaran kepada pemerintah kota Tual untuk tujuan peningkatan efisiensi pemasaran

2. Memberikan kontribusi positif terhadap khasanah perkembangan ilmu pengetahuan bidang pemasaran hasil perikanan

3. Penelitian ini dapat juga menjadi rujukan bagi para peminat bidang ilmu pengembangan pemasaran produk perikanan.

\section{METODE PENELITIAN}

\subsection{Tempat dan Waktu Penelitian}

Di kota Tual terdapat empat kecamatan yakni, kecamatan dullah selatan, kecamatan dullah utara, kecamatan tayando tam dan kecamatan pulau-pulau kur. Penelitian ini dilakukan di Kecamatan Dullah Utara, pemilihan 
lokasi tersebut dilakukan secara purposive dengan dasar bahwa daerah tersebut merupakan sentra produksi utama rumput laut di kota Tual. Waktu penelitian dilakukan selama 4 bulan di mulai bulan Februari - Mei 2011.

\subsection{Metode Pengambilan Sampel}

Metode pengambilan sampel dalam penelitian ini menggunakan teknik sampling beberapa tahap, dimulai dari sampel petani rumput laut dan sampel lembaga pemasaran yang telibat dalam pemasaran rumput laut.

\section{Sampel Petani Rumput Laut}

Jumlah sampel petani yang diambil tergantung pada heterogenitas populasi dan tingkat representativitas yang dikehendaki. Di kota Tual terdapat 40 desa yang tersebar di empat kecamatan, sedangkan di Kecamatan Dullah Utara terdapat 11 desa, dimana terdapat 3 desa sebagai penghasil rumput laut terbesar dan diperkirakan terdapat sekitar 100 orang petani rumput laut. Jumlah ini diambil semua secara sensus sebagai sampel penelitian. Resiko bias dalam pengambilan sampel diharapkan dapat diminimisasi dan kesimpulan yang ditarik dapat mewakili populasi yang diteliti (Nasution, 2003).

\section{Sampel Lembaga Pemasaran}

Pengambilan sampel lembaga pemasaran dilakukan dengan menggunakan metode non Probability sampling dengan teknik snowball sampling, metode ini dianggap cukup representatif dalam studi mengenai pemasaran. Data dari responden merupakan informasi awal yang digunakan sebagai patokan untuk menelusuri lembaga pemasaran pada setiap level/saluran pemasaran sampai tingkat pengecer/konsumen akhir. Jumlah sampel lembaga pemasaran ditentukan sesuai dengan kemampuan peneliti dengan catatan tidak mengurangi representasi populasi dari total masing-masing lembaga pemasaran mulai dari pedagang pengumpul, pedagang besar dan konsumen.

\subsection{Metode Pengumpulan Data}

Data yang diperlukan dalam penelitian ini dapat dikelompokkan atas dua kategori yaitu : data sekunder dan data primer. Untuk merrperoleh kedua data tersebut secara akurat maka dilakukan teknik pengambilan data dengan observasi, studi kepustakaan serta wawancara.

\subsection{Metode Analisis Data \\ 1. Struktur Pasar}

Analisis struktur pasar ditujukan untuk mengetahui jenis pasar rumput laut di lokasi penelitian. Komponen struktur pasar yang diteliti meliputi :

a. Hambatan keluar masuk pasar.

Dianalisis dengan Minimum Efficiency Scale (MES). Jika nilai MES lebih besar dari $10 \%$ mengindikasi hambatan masuk cukup tinggi.

$$
\text { Dimana, MES }=\frac{\text { Penjualan Pedagang Terbesar }}{\text { Produksi Rumput Laut di kota Tual }}
$$

\section{b. Pengetahuan Pasar}

Pengetahuan pasar diukur dengan indikator tingkat pengetahuan pasar terutama mengenai informasi harga baik bagi petani maupun lembaga pemasaran lainnya.

c. Pangsa Pasar

Analisis ini dilakukan untuk melihat pangsa pasar yang menggambarkan keuntungan yang diperoleh lembaga pemasaran dari hasil penjualannya. Setiap lembaga pemasaran memiliki pangsa pasar yang berbeda-beda berkisar antara $0-100 \%$ dari total penjualan seluruh pasar (Firdaus, 2008).

\begin{tabular}{cccc} 
Tabel 1 Perhitungan Pangsa Pasar (Market Share) \\
$\begin{array}{c}\text { Lembaga } \\
\text { Pemasaran }\end{array}$ & $\begin{array}{c}\text { Kapasitas Produk yang dapat } \\
\text { diserap pasar }\end{array}$ & Market Share & $\begin{array}{c}\text { Konsentrasi Rasio } \\
(\%)\end{array}$ \\
\hline 1 & $\mathrm{a}$ & $\mathrm{a} / \mathrm{x}$ & $(\mathrm{a} / \mathrm{x}) 100$ \\
2 & $\mathrm{~b}$ & $\mathrm{~b} / \mathrm{x}$ & $(\mathrm{b} / \mathrm{x}) 100$ \\
3 & $\mathrm{C}$ & $\mathrm{c} / \mathrm{x}$ & $(\mathrm{c} / \mathrm{x}) 100$ \\
$\ldots$ & $\ldots$ & $\ldots$ & $\ldots$ \\
$\mathrm{n}$ & $\mathrm{M}$ & $\mathrm{m} / \mathrm{x}$ & $(\mathrm{m} / \mathrm{x}) 100$ \\
\hline Total & $\mathrm{a}+\mathrm{b}+\mathrm{c}+\ldots+\mathrm{m}=\mathbf{x}$ & 1 & 100 \\
\hline
\end{tabular}

d. Konsentrasi Pasar

CR4 (Concentration

Biggest Four). Merupakan
Ratio for The

pembeli yang mempunyai pangsa pasar terbesar dari suatu wilayah pasar.

penjumlahan 4 Rumus : $C R 4=S_{1}+S_{2}+S_{3}+S_{4}$ 
Dimana : CR4 = Concentration Ratio for The Biggest Four

$\mathrm{Si}=$ pangsa pasar dari pedagang ke-1

Ketentuannya sebagai berikut:

CR4 $\geq 40 \%$, bahwa struktur pasar cenderung oligopoli atau oligopsoni.

CR4 $\leq 40 \%$, bahwa struktur pasar cenderung ke persaingan sempurna.

\section{Perilaku Pasar.}

Perilaku pasar rumput laut di kota Tual di analisis secara deskriptif dengan tujuan untuk memperoleh informasi perilaku lembaga pemasaran dalam pemasaran rumput laut. Adapun perilaku yang diamati adalah, proses penjualan dan pembelian, sistem pembayaran serta kerjasama.

\section{Penampilan Pasar.}

Penampilan pasar rumput laut di kota Tual dianalisis dengan menggunakan marjin pemasaran, analisis bagian harga yang diterima oleh petani (farmer's share) serta analisis rasio keuntungan dan biaya pemasaran.

a. Marjin Pemasaran

Analisis marjin pemasaran digunakan untuk menghitung marjin pemasaran, distribusi marjin dan share keuntungan serta share biaya lembaga pemasaran. dan rasio keuntungan dengan biaya dari masing-masing lembaga pemasaran.

- Marjin pemasaran dihitung dengan rumus :

Keterangan :

$$
M=P_{r}-P_{f} \text { atau } M=K P+B P
$$

$$
\begin{aligned}
& \mathrm{M}=\text { Marjin Pemasaran } \\
& P_{r}=\text { Harga tingkat konsumen } \\
& P_{f}=\text { Harga tingkat petani } \\
& \mathrm{KP}=\text { Keuntungan lembaga pemasaran } \\
& \mathrm{BP}=\text { Biaya Pemasaran }
\end{aligned}
$$

- Distribusi Marjin dapat dijelaskan sebagai berikut :

$$
D M i=\frac{M i}{\text { MPtotal }} \times 100 \%
$$

Keterangan :

$$
\begin{array}{ll}
\text { DMi } & \quad=\text { Distribusi marjin } \\
M i & =\text { Marjin pemasaran ke-i } \\
\text { MPtotal } & =\mathrm{P}_{\mathrm{r}}-\mathrm{P}_{\mathrm{f}}
\end{array}
$$

- Share keuntungan lembaga pemasaran ke i adalah :

$$
S_{k i}=\frac{K_{i}}{P_{r}-P_{f}} x 100 \%, K_{i}=P_{j i}-P_{b i}-b_{i j}
$$

Keterangan :

$S k i=$ Share keuntungan lembaga pemasaran ke $\mathrm{i}$
$K i=$ Keuntungan lembaga pemasaran ke $\mathrm{i}$

$P j i=$ Harga jual lembaga pemasaran ke i

$P b i=$ Harga beli lembaga pemasaran ke i

$B i j$ = Biaya pemasaran lembaga pemasaran ke $\mathrm{i}$

dari berbagai jenis biaya ( $\mathrm{i}=1$ pengumpul $; \mathrm{i}=2$

pedagang besar $; i=3$ pengecer)

- Share biaya lembaga pemasaran ke i dihitung dengan rumus :

$$
S p=\frac{P_{f}}{P_{r}} \times 100 \%
$$

Keterangan :

$S_{b i}=$ Share biaya pada lembaga pemasaran ke i

$b_{i}=$ Biaya pemasaran pada lembaga pemasaran ke i

$P_{r}=$ Harga pada pengecer

$P_{f}=$ Harga pada petani

b. Analisis bagian harga yang diterima oleh petani (farmer's share)

Share harga yang diterima petani $(S p)$ dihitung dengan rumus :

$$
S_{p}=\frac{P_{f}}{P_{r}} \times 100 \%
$$

Keterangan :

$$
\begin{aligned}
& S p=\text { Share harga pada petani } \\
& P r=\text { Harga pada pengecer } \\
& P f=\text { Harga pada petani }
\end{aligned}
$$

c. Analisis rasio keuntungan dan biaya pemasaran.

Rasio keuntungan dengan biaya untuk masing-masing lembaga pemasaran dihitung dengan rumus :

$$
R_{K B i}=\frac{K_{i}}{B_{i}}
$$

Keterangan :

$$
\begin{aligned}
R_{K B i}= & \text { Rasio keuntungan dengan lembaga } \\
& \text { pemasaran ke } \mathrm{i}(\mathrm{i}=1 \text { pengumpul } ; \mathrm{i}=2 \\
& \text { pedagang besar } ; \mathrm{i}=3 \text { pengecer }) \\
K_{i}= & \text { Keuntungan lembaga pemasaran ke } \mathrm{i} \\
B_{i}= & \text { Biaya dari lembaga pemasaran ke } \mathrm{i}
\end{aligned}
$$

\section{HASIL DAN PEMBAHASAN \\ 3.1. Pemasaran Rumput Laut (Eucheuma cottonii)}

Hampir seluruh perairan disepanjang laut di kota Tual digunakan untuk budidaya rumput laut, termasuk juga di Kecamatan Dullah Utara, kondisi perairan Kecamatan Dullah Utara yang 
terletak didalam teluk, sehingga mengakibatkan kegiatan budidaya tidak terlalu berpengaruh terhadap ancaman cuaca, terutama gelombang dan angin. Disamping itu lokasi desa-desa di Kecamatan Dullah Utara yang terletak dipinggiran pantai mengakibatkan sebagian besar penduduk desanya melakukan kegiatan budidaya rumput laut.

\subsubsection{Petani Rumput Laut (Eucheuma cottonii)}

Rumput laut yang dihasilkan oleh petani dalam bentuk rumput laut kering, dengan harga rata-rata $\mathrm{Rp} 6.363 / \mathrm{kg}$. dengan kadar air berkisar antara $35-40$ persen. Dengan rendemen rumput laut berkisar 20-25 persen yakni $5 \mathrm{~kg}$ rumput laut basah menjadi $1 \mathrm{~kg}$ rumput laut kering.

\section{Pedagang Pengumpul Desa}

Pedagang pengumpul desa berfungsi sebagai pembeli rumput laut kering dari para petani rumput laut. Harga beli rumput laut di tingkat pedagang pengumpul desa adalah berkisar Rp. 6.363. Mereka tinggal didesa dan hidup berdampingan dengan para petani. Untuk mengikat para petani rumput laut di desa, umumnya para pedagang pengumpul desa memberikan pinjaman modal serta pinjaman untuk kebutuhan hidup kepada petani.rumput laut. Sehingga petani rumput laut menjadi terikat dan harus menjual hasil rumput lautnya kepada pedagang pengumpul desa.

\subsubsection{Pedagang Pengumpul Kecamatan}

Pedagang pengumpul kecamatan tinggal di Ibu kota Kecamatan dalam hal ini di Desa Dullah, mereka membeli hasil rumput laut kering dari pedagang pengumpul desa dan juga langsung kepada petani.

\subsubsection{Pedagang Lokal}

Pedagang lokal umumnya bertindak sebagai perantara saja, mereka tidak melakukan fungsi pengepakan dan sortasi karena umumnya sudah dilakukan oleh pedagang pengumpul kecamatan. Secara kasat mata pedagang pengumpul kecamatan bisa secara langsung menjual rumput laut kering kepada pedagang besar antar pulau, karena jarak antara pedagang lokal dengan pedagang besar antar pulau relatif dekat. Akan tetapi para pedagang pengumpul kecamatan sebagian besar menjual rumput laut keringnnya kepada pedagang lokal, hal ini disebabkan karena adanya hubungan kerjasama yang cukup kuat antara pedagang lokal dan pedagang pengumpul kecamatan.

Pedagang Besar Antar Pulau

Pedagang besar adalah pedagang yang membeli rumput laut dari para pedagang pengumpul maupun pedagang lokal, berdasarkan hasil pengamatan dan wawancara dilapangan didapat ada 7 pedagang besar yang ada di Kota Tual. Umumnya para pedagang besar ini memiliki beberapa pedagang pengumpul sebagai kaki tangannya yang dapat memasok rumput laut kering secara terus menerus. Bahkan untuk memperoleh hasil rumput laut yang berkelanjutan mereka memberikan pinjaman modal usaha kepada para pedagang pengumpul. Disamping itu dengan adanya pola kerjasama dalam memberikan keuntungan diantara keduanya yang terus menerus dipertahankan, menjadi pengikat antara para pedagang pengumpul/lokal dengan pedagang besar.

\subsection{Saluran Pemasaran Rumput Laut (Eucheuma cottonii)}

Saluran pemasaran rumput laut di Kecamatan Dullah Utara terdiri dari simpulsimpul pengumpul desa, pengumpul kecamatan, pedagang lokal dan pedagang antar pulau. Dari hasil pengamatan dan wawancara terhadap 100 responden petani rumput laut di tiga desa Kecamatan Dullah Utara didapat jalur distribusi rumput laut dengan tiga pola yang berbeda. Untuk lebih jelasnya dapat dilihat pada Gambar 1.

Pada Gambar 1 dapat dilihat bahwa pola 1 merupakan volume pemasaran yang tertinggi yakni sebesar 85 persen dengan jumlah $67.039 \mathrm{~kg}$ hasil rumput laut kering yang dipasarkan. Pola 2 sebesar 10 persen dengan jumlah $7.328 \mathrm{~kg}$ hasil rumput laut kering yang dipasarkan. Harga rumput laut yang berlaku saat dilakukan pengamatan dan wawancara adalah rata-rata berkisar Rp. 6.363/kg. kadar air berkisar antara 35 - 40 persen.

Variasi harga yang terjadi di Kecamatan Dullah Utara selain disebabkan oleh kualitas rumput laut yang dimiliki petani, juga karena adanya faktor ikatan modal dan pinjaman biaya hidup dari pedagang pengumpul desa dan pedagang pengumpul kecamatan kepada petani rumput laut. Hal tersebut menyebabkan posisi tawar petani rumput laut menjadi lemah. Disamping itu juga petani tidak memiliki kemampuan untuk mengakses informasi pasar.

\subsection{Struktur Pasar Rumput Laut (Eucheuma cottonii)}

Analisis struktur pasar ditujukan untuk mengetahui jenis pasar rumput laut di Kecamatan Dullah Utara kota Tual. Komponen struktur pasar yang dianalisis meliputi : hambatan keluar masuk pasar, pengetahuan pasar, pangsa pasar dan konsentrasi pasar. 


\section{Hambatan Masuk Pasar}

Hasil analisis MES (Minimum Efficiency scale) pada tingkat pedagang pengumpul desa sebesar 16,49 persen, pada tingkat pedagang

pengumpul kecamatan sebesar 16,61 persen, pada tingkat pedagang lokal sebesar 19,31 persen serta pada tingkat pedagang besar antar pulau sebesar 23,61 persen. Untuk lebih jelasnya dapat dilihat pada Tabel 2.

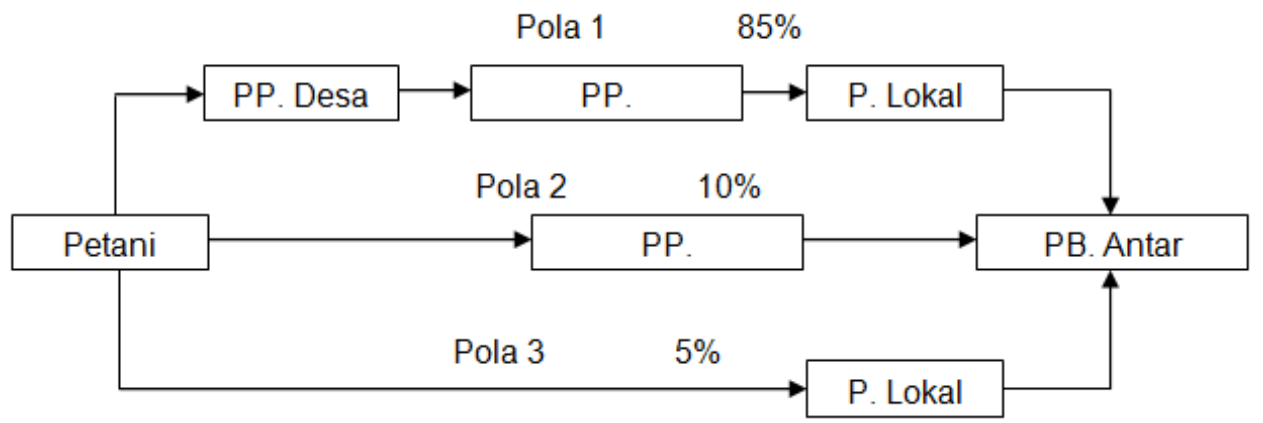

Gambar 1. Saluran Pemasaran Dalam Usaha Tani Rumput Laut

Tabel 2. Hasil Analisis MES (Minimum Efficiency Scale) Pada Tingkat Pedagang Rumput Laut (Eucheuma cottonii)

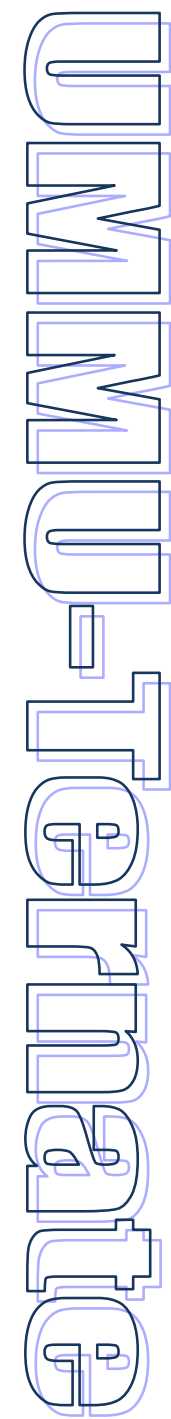

\begin{tabular}{clc}
\hline No. & \multicolumn{1}{c}{ Tingkat Pedagang } & $\begin{array}{c}\text { MES (Minimum Efficiency Scale) } \\
(\%)\end{array}$ \\
\hline 1 & Pedagang Pengumpul Desa & 16,49 \\
2 & Pedagang Pengumpul Kecamatan & 16,61 \\
3 & Pedagang Lokal & 19,31 \\
4 & Pedagang Besar Antar Pulau & 23,61 \\
\hline
\end{tabular}

Tabel 2 tersebut terlihat bahwa nilai MES semua tingkatan pedagang diatas 10 persen, yang menggambarkan hambatan yang cukup besar untuk masuk kedalam pasar rumput laut, baik ditingkat pedagang pengumpul desa, pedagang pengumpul kecamatan, pedagang lokal maupun pedagang besar antar pulau. Karena selain membutuhkan modal yang cukup besar juga disebabkan adanya ikatan yang kuat antara para pedagang maupun petani rumput laut itu sendiri.

\section{Pengetahuan Pasar}

Pengetahuan pasar yang diperlukan dalam pemasaran rumput laut adalah terkait dengan informasi harga yang terbentuk antara para pedagang pengumpul dengan pedagang besar. Berdasarkan hasil pengamatan dan wawancara dengan 100 responden petani rumput laut. Terjadinya perubahan harga sangat dipengaruhi oleh kondisi musim. Karena sistem pengeringan rumput laut menggunakan matahari, sehingga jika musim hujan sangat mempengaruhi kadar kekeringan dari produk rumput laut itu sendiri.

Dalam mengakses informasi pasar, biasanya para petani mengetahui dari sesama petani rumput laut atau dari pedagang pengumpul yang bukan menjadi langganannya, akan tetapi informasi harga yang diperoleh petani tidak dapat membuat posisi tawar para petani rumput laut menjadi lebih kuat atau menjual hasil rumput laut kepada pedagang pengumpul lain. Hal ini disebabkan karena adanya keterikatan antara petani dengan pedagang pengumpul sehingga petani harus menjual hasil panennya kepada pedagang pengumpul yang telah menjadi langganan tetapnya.

3. Pangsa Pasar dan Konsentrasi Pasar Rumput Laut (Eucheuma cottonii)

Tingkat konsentrasi pasar mengukur derajat penguasaan pasar oleh empat pedagang, semakin besar penguasaan pasar terdapat kecenderungan keempat pedagang tersebut memiliki kekuatan monopoli. Sehingga ada kecenderungan terjadi penentuan harga yang tidak seimbang (Kohls, 2002).

Rasio konsentrasi pedagang dilakukan pada empat pedagang terbesar pada masingmasing tingkat pemasaran di Kecamatan Dullah Utara dengan pengelompokan empat pedagang tersebut berdasarkan pada pedagang yang memiliki pangsa pasar terbesar, sedangkan untuk menghitung pangsa pasar dilihat pada volume penjualan yang dilakukan dalam pemasaran 
rumput laut tersebut. Untuk lebih jelasnya dapat dilihat pada Tabel 3.

Dari hasil analisis didapat nilai CR4 untuk pedagang pengumpul desa yakni sebesar 54,29 persen, dan berdasarkan kriteria CR4 jika lebih besar dari 40 persen maka hal ini menunjukkan bahwa struktur pasar cenderung oligopsoni.

Dari hasil analisis didapat nilai CR4 untuk pedagang pengumpul kecamatan yakni sebesar 60,95 persen, dan berdasarkan kriteria CR4 jika lebih besar dari 40 persen maka hal ini menunjukkan bahwa struktur pasar cenderung oligopsoni.

Dari hasil analisis didapat nilai CR4 untuk pedagang lokal yakni sebesar 70,44 persen, dan berdasarkan kriteria CR4 jika lebih besar dari 40 persen maka hal ini menunjukkan bahwa struktur pasar cenderung oligopsoni.

Hal yang sama juga terjadi pada pedagang besar antar pulau dimana dari hasil analisis didapat nilai CR4 yakni sebesar 70,29 persen, dan berdasarkan kriteria CR4 jika lebih besar dari 40 persen maka hal ini menunjukkan bahwa struktur pasar cenderung oligopsoni.

Dengan demikian berdasarkan hasil analisis CR4 pada setiap lembaga pemasaran, maka disimpulkan bahwa struktur pasar rumput laut di Kecamatan Dullah Utara kota Tual adalah oligopsoni.

Tabel 3. Pangsa Pasar dan Konsentrasi Pasar Pedagang Pengumpul Desa.

\begin{tabular}{ccccc} 
No. & Kapasitas Produk & Market Share & Rasio $(\%)$ & CR4 $(\%)$ \\
\hline 1 & 5,600 & 0.12 & 12.28 & 12.28 \\
2 & 7,520 & 0.16 & 16.49 & 16.49 \\
3 & 2,730 & 0.06 & 5.99 & \\
4 & 3,250 & 0.07 & 7.13 & \\
5 & 2,510 & 0.06 & 5.50 & \\
6 & 6,321 & 0.14 & 13.86 & 13.86 \\
7 & 4,300 & 0.09 & 9.43 & \\
8 & 5,310 & 0.12 & 11.64 & \\
9 & 2,750 & 0.06 & 6.03 & 11.66 \\
10 & 5,320 & 0.12 & 11.66 & 54.29 \\
\hline Total & $\mathbf{4 5 , 6 1 1}$ & $\mathbf{1}$ & $\mathbf{1 0 0}$ & \\
\hline
\end{tabular}

Tabel 4. Pangsa Pasar dan Konsentrasi Pasar Pedagang Pengumpul Kecamatan.

\begin{tabular}{ccccc}
\hline No. & Kapasitas Produk & Market Share & Rasio (\%) & CR4 (\%) \\
\hline 1 & 10,675 & 0.15 & 15.42 & 15.42 \\
2 & 8,750 & 0.13 & 12.64 & \\
3 & 9,530 & 0.14 & 13.76 & \\
4 & 8,760 & 0.13 & 12.65 & \\
5 & 10,335 & 0.15 & 14.92 & 14.92 \\
6 & 11,500 & 0.17 & 16.61 & 16.61 \\
7 & 9,700 & 0.14 & 14.01 & 14.01 \\
\hline Total & 69,250 & 1 & 100 & 60.95 \\
\hline
\end{tabular}

Tabel 5. Pangsa Pasar dan Konsentrasi Pasar Pedagang Lokal.

\begin{tabular}{ccccc}
\hline No. & Kapasitas Produk & Market Share & Rasio (\%) & CR4 (\%) \\
\hline 1 & 20,430 & 0.18 & 18.43 & 18.43 \\
2 & 16,30 & 0.15 & 14.71 & \\
3 & 17,503 & 0.16 & 15.79 & 15.79 \\
4 & 21,400 & 0.19 & 19.31 & 19.31 \\
5 & 16,460 & 0.15 & 14.85 & \\
6 & 18,750 & 0.17 & 16.92 & 16.92 \\
\hline Total & 110,843 & 1 & 100 & 70.44 \\
\hline
\end{tabular}


Tabel 6. Pangsa Pasar dan Konsentrasi Pasar Pedagang Besar Antar Pulau.

\begin{tabular}{ccccc}
\hline No. & Kapasitas Produk & Market Share & Rasio $(\%)$ & CR4 $(\%)$ \\
\hline 1 & 50,530 & 0.13 & 12.54 & 12.54 \\
2 & 43,015 & 0.11 & 10.68 & \\
3 & 72,270 & 0.18 & 17.94 & 17.94 \\
4 & 35,700 & 0.09 & 8.86 & \\
5 & 41,000 & 0.10 & 10.18 & \\
6 & 95,130 & 0.24 & 23.61 & 23.61 \\
7 & 65,240 & 0.16 & 16.19 & 16.19 \\
\hline Total & $\mathbf{4 0 2 , 8 8 5}$ & 1 & 100 & $\mathbf{7 0 . 2 9}$ \\
\hline
\end{tabular}

\subsection{Perilaku Pasar Rumput Laut (Eucheuma cottonii)}

Perilaku pasar rumput laut di Kecamatan Dullah Utara di analisis secara deskriptif dengan tujuan untuk memperoleh informasi perilaku lembaga pemasaran dalam pemasaran rumput laut. Adapun perilaku yang diamati adalah proses penjualan, pembelian dan pembentukan harga, sistem pembayaran serta bentuk-bentuk kerjasama.

1. Proses Penjualan, Pembelian dan Pembentukan Harga Rumput Laut

Perilaku pasar dapat diketahui dengan mengamati praktek penjualan dan pembelian rumput laut di Kecamatan Dullah Utara serta kerja sama diantara pelaku pemasaran.

Penentuan harga beli di tingkat petani rumput laut oleh pedagang pengumpul setempat dengan mekanisme yang didasarkan adanya ikatan kerja sama dalam bentuk pinjaman modal serta pinjaman untuk kebutuhan hidup petani rumput laut sehari-hari. Sehingga setiap pedagang pengumpul desa maupun pedagang pengumpul kecamatan memiliki petani rumput laut yang dengan setia tetap menjual hasil panennya kepada para pedagang pengumpul yang mana merupakan langganannya, dimana petani bertindak sebagai penerima harga.

Pola pemasaran pertama dan kedua yang terjadi pada umumnya, pedagang pengumpul desa menetapkan harga untuk membeli rumput laut kepada petani rumput laut berdasarkan pada harga beli yang ditetapkan oleh pedagang pengumpul kecamatan. Selanjutnya dari pedagang pengumpul kecamatan menetapkan harga beli kepada pedagang pengumpul desa berdasarkan harga beli yang telah ditetapkan oleh pedagang lokal dan pedagang besar.

Sedangkan pedagang besar menetapkan harga beli kepada pedagang lokal maupun pedagang pengumpul kecamatan berdasarkan pada harga yang ditetapkan oleh industri atau eksportir yang menjadi langganannya. Sehingga dengan melihat fakta tersebut, maka pangkal dalam penentuan harga diawali dari pedagang besar antar pulau yang lebih dominan, yang berpengaruh hingga petani rumput laut. Sedangkan disisi lain petani rumput laut menjual hasil panennya kepada pedagang pengumpul disebabkan karena adanya pinjaman modal serta pinjaman biaya hidup sehari-hari.

Dengan demikian cukup beralasan jika petani rumput laut merupakan pihak yang memiliki posisi tawar paling rendah dalam penentuan harga, sehingga hanya bertindak sebagai penerima harga.

Dilain pihak pada pola pemasaran ketiga dimana petani rumput laut mendapatkan harga beli berdasarkan informasi dari pedagang lokal lainnya, hal ini disebabkan karena tidak adanya ikatan hubungan pinjaman modal maupun biaya hidup dengan para pedagang pengumpul, sehingga petani bebas untuk menjual hasil panennya kepada pedagang lokal. Dimana hubungan petani yang menjual hasil panennya kepada pedagang lokal umumnya memiliki hubungan kekerabatan yang cukup kuat.

Pemerintah dapat berperan menyeimbangkan dimana perusahaan menentukan harga pada harga sama dengan marginal cost sehingga konsumen membayar lebih murah dan mendapat output lebih banyak (Joesron 2003).

Penentuan harga merupakan hal yang sangat penting dalam peningkatan pendapatan usaha para petani rumput laut. Berdasarkan hasil pengamatan dan wawancara dengan responden maupun beberapa perangkat struktural di kecamatan maupun di dinas yang terkait, menunjukan bahwa praktek penentuan harga rumput laut dianalisis dari tingkat petani hingga pedagang besar antar pulau, dapat dikatakan bahwa praktek penentuan harga yang terjadi 
dalam pemasaran rumput laut tersebut mengarah kepada pasar oligopsoni.

\section{Sistem Pembayaran}

Umumnya petani rumput laut setelah melakukan pengeringan rumput laut langsung menjual hasil rumput lautnya kepada pedagang pengumpul baik didesa maupun di kecamatan atau beberapa petani yang tergolong tidak terikat dengan kedua pedagang pengumpul tersebut langsung menjual hasil panennya kepada pedagang lokal.

Terlepas dari tempat transaksi yang dilakukan, sistem pembayaran terhadap hasil panen rumput laut yang terjadi cukup beragam. Sistem yang dimaksud meliputi pembayaran tunai serta diberi panjar sebelum para pedagang menerima hasil panen rumput laut, namun harga jual tetap ditentukan saat panen dengan harga yang berlaku dan sistem harga ditetapkan oleh pedagang pengumpul.

Cara pembayaran yang berlaku dimaksud untuk mengikat para petani rumput laut. Dengan demikian ada ketergantungan antara petani rumput laut dengan pedagang pengumpul dalam hal pinjaman modal maupun pinjaman biaya hidup sehari-hari. Setidaknya kondisi tersebut merupakan perangkap pedagang pengumpul untuk mengikat para petani rumput laut untuk kepastian untuk memperoleh hasil panen rumput laut. Pembelian rumput laut di Kecamatan Dullah Utara didominasi oleh pedagang pengumpul desa sebanyak 85 persen, pedagang pengumpul kecamatan sebanyak 10 persen dan pedagang lokal sebanyak 5 persen.

\section{Kerja sama}

Pedagang pengumpul yang berada di Kecamatan Dullah Utara berdasarkan metode Snow ball yang dilakukan dilapangan didapat berjumlah 17 orang, yang terdiri dari pedagang pengumpul desa sebanyak 10 orang dan pedagangan pengumpul kecamatan sebanyak 7 orang. Pedagang pengumpul menampung hasil panen rumput laut dari petani rumput laut.

Setiap pedagang pengumpul memiliki ikatan dengan petani rumput laut yang jumlahnya cukup bervariasi, dimana ada yang memiliki hingga 20 petani rumput laut, namun ada juga yang memiliki kurang dari 10 petani rumput laut. Setiap petani rumput laut diharuskan menjual hasil panennya kepada pedagang pengumpul yang telah menjadi langganan dan telah terikat.

Kerja sama yang terjalin antara pedagang pengumpul dengan para petani rumput laut harusnya disertai dengan pembinaan dan pengembangan yang berkelanjutan, disamping itu juga kerja sama harus memperhatikan prinsipprinsip saling ketergantungan, saling memperkuat dan menguntungkan. Akan tetapi faktanya tidak adanya ikatan formal yang kuat seperti adanya hubungan organisasi atau koperasi. Sehingga kerja sama tersebut hanya terikat pada mekanisme pasar. Dengan demikian kondisi tersebut cenderung merugikan pihak petani rumput laut. Upaya kelembagaan harus dipandang sebagai suatu prasyarat keharusan (necessary condition) bagi suatu rekonstruksi dan restrukturisasi ekonomi (Wibowo, 2004).

\subsection{Penampilan Pasar Rumput Laut (Eucheuma cottonii).}

Penampilan atau kinerja pasar adalah penilaian terhadap sumberdaya ekonomi. Penampilan pasar rumput laut di Kecamatan Dullah Utara dianalisis dengan menggunakan marjin pemasaran, analisis bagian harga yang diterima oleh petani (farmer's share) serta analisis rasio keuntungan dan biaya pemasaran.

Efisiensi pemasaran diindikasikan oleh besarnya nilai keuntungan yang diterima oleh masing-masing para pelaku pemasaran, dapat dilakukan dengan menganalisis marjin pemasaran dan share petani. Semakin tinggi proporsi harga yang diterima oleh petani rumput laut, maka sistem pemasaran yang terjadi semakin efisien. Besar nilai keuntungan yang diterima oleh masing-masing pelaku pemasaran relatif terhadap harga yang dibayar oleh konsumen atau relatif terhadap biaya pemasaran terkait dengan peran yang dilakukan oleh masing-masing pelaku pemasaran.

\section{Marjin Pemasaran dan Farmer's Share}

Marjin pemasaran merupakan perbedaan antara harga yang dibayarkan konsumen dengan harga yang diterima petani. Komponen margin pemasaran ini terdiri dari: 1) biaya-biaya yang diperlukan lembaga-lembaga pemasaran untuk melakukan fungsi-fungsi pemasaran yang disebut biaya pemasaran atau biaya fungsional dan 2) keuntungan lembaga pemasaran.

Analisis marjin pemasaran dilakukan mulai dari petani rumput laut, pedagang pengumpul desa, pedagang pengumpul kecamatan, pedagang lokal hingga pedagang besar antar pulau. Marjin pemasaran tertinggi dari hasil pemasaran rumput laut dari petani hingga pedagang besar antar pulau terletak pada pola pemasaran pertama dengan nilai sebesar Rp. $5.540 / \mathrm{kg}$. Tingginya marjin pemasaran pada pola pertama ini disamping disebabkan karena panjangnya saluran pemasaran juga harga rumput laut disesuaikan 
dengan harga-harga yang telah disepakati disetiap saluran pemasaran.

Sedangkan marjin pemasaran terendah diperoleh pada pola pemasaran ketiga yakni sebesar Rp. 3,907.14/kg. rendahnya marjin pemasaran pada pola ketiga ini lebih disebabkan karena adanya hubungan kekerabatan yang cukup kuat antara petani rumput laut dengan pedagang lokal, sehingga penetapan harga beli oleh pedagang lokal disesuaikan dengan harga beli pada pedagang pengumpul. Sedangkan harga jual kepada pedagang besar disesuaikan dengan kesepakatan harga yang telah disepakati.

Marjin pemasaran pada setiap pola pemasaran diperoleh dengan cara mengurangi harga jual dimasing-masing tingkatan pedagang dengan harga jual ditingkat petani rumput laut. Berdasarkan hasil analisis tersebut diperoleh bahwa semakin banyak jumlah pelaku pemasaran yang terlibat dapat mengakibatkan marjin menjadi lebih besar. Akan tetapi jika dilihat dari segi presentase bagian harga yang diterima petani rumput laut pada tabel tampaknya cukup besar pada masing-masing pola pemasaran. Untuk lebih jelasnya tentang marjin pemasaran, share petani serta komponen biaya pemasaran dapat dilihat pada lampiran tabel 1, tabel 2 dan tabel 3 .

Dari ketiga tabel tersebut juga dapat dilihat share petani terkecil diperoleh pada pola pemasaran pertama yakni 53,83 persen, pola pemasaran kedua sebesar 57,25 persen, sedangkan share petani terbesar terdapat pada pola pemasaran ketiga yakni sebesar 67,44 persen. Sehingga dapat dikatakan bahwa pola pemasaran ketiga menunjukan pola pemasaran yang lebih efisien jika dibandingkan dengan pola pemasaran pertama dan pola pemasaran kedua.

Komponen biaya yang dikeluarkan selama proses pemasaran masih tergolong relatif rendah, jika dibandingkan dengan komponen harga jual dan harga beli yang rata-rata diatas 50 persen untuk setiap pelaku pemasaran.

\section{Rasio Keuntungan dan Biaya Pemasaran.}

Rasio keuntungan dan biaya pemasaran rumput laut disajikan pada tabel 7 . hasil analisis menunjukan bahwa rasio keuntungan biaya terbesar terjadi pada pola pemasaran pertama yaitu 23,07 dan yang terkecil pada pola pemasaran ketiga yaitu sebesar 15,41. Sedangkan rasio keuntungan biaya untuk pola pemasaran kedua adalah sebesar 16,83.

Dengan demikian pola pemasaran ketiga merupakan pola pemasaran dengan rasio keuntungan dan biaya yang lebih menguntungkan para petani maupun pelaku pemasaran. Efisiensi pemasaran akan tercipta apabila berada dalam mekanisme pasar bersaing sempurna dengan besarnya marjin pemasaran konstan dan bagian harga yang diterima petani rumput laut cukup besar.

\begin{tabular}{clccc}
\multicolumn{6}{c}{ Tabel 7. Rasio Keuntungan dan Biaya Pemasaran Rumput Laut (Eucheuma cottonii) } \\
$\begin{array}{c}\text { Saluran } \\
\text { Pemasaran }\end{array}$ & Lembaga Pemasaran & $\begin{array}{c}\text { Keuntungan } \\
(\text { Rp) }\end{array}$ & $\begin{array}{c}\text { Biaya } \\
(\text { Rp) }\end{array}$ & $\begin{array}{c}\text { Rasio } \\
\text { Keuntungan/biaya }\end{array}$ \\
\hline \multirow{5}{*}{ Pertama } & PP. Desa & 294.37 & 115.63 & 2.55 \\
& PP. Kecamatan & $1,022.86$ & 200.00 & 5.11 \\
& P. Lokal & $1,659.23$ & 131.25 & 12.64 \\
& PB. Antar Pulau & $1,554.92$ & 561.75 & 2.77 \\
\cline { 2 - 5 } & Total & $4,531.38$ & $1,008.63$ & 23.07 \\
\hline \multirow{3}{*}{ Kedua } & PP. Kecamatan & $2,813.33$ & 200.00 & 14.07 \\
& PB. Antar Pulau & $1,554.92$ & 561.75 & 2.77 \\
\cline { 2 - 5 } & Total & $4,386.25$ & 761.75 & 16.84 \\
\hline \multirow{2}{*}{ Ketiga } & P. Lokal & $1,659.23$ & 131.25 & 12.64 \\
& PB. Antar Pulau & $1,554.92$ & 561.75 & 2.77 \\
\cline { 2 - 5 } & Total & $3,214.15$ & 693.00 & 15.41 \\
\hline
\end{tabular}

Walaupun pasar berada dalam mekanisme pasar bersaing tidak sempurna yang disebabkan adanya ikatan yang kuat sehingga pembeli yang lebih dominan, namun berdasarkan hasil analisis marjin pemasaran, share petani serta rasio keuntungan dan biaya menunjukan bahwa pola pemasaran ketiga yang cukup efisien untuk dilakukan karena bagian harga serta keuntungan dan biaya yang diperoleh cukup memberikan insentif untuk meningkatkan usaha rumput lautnya dibandingkan dengan pola pemasaran lainnya. Dengan demikian, ikatan yang terbentuk pada pola pemasaran ketiga tidak merugikan para petani rumput laut. 


\section{KESIMPULAN DAN SARAN \\ 4.1. Kesimpulan}

Berdasarkan penelitian yang dilakukan, dapat disimpulkan sebagai berikut :

1. Pola pemasaran yang terjadi masih belum efisien, hal ini dilihat dari struktur pasar ditingkat pedagang pengumpul hingga pedagang besar antar pulau cenderung bersifat oligopsoni (banyak penjual sedikit pembeli), sehingga muncul pedagang yang dominan dan memiliki pangsa pasar yang besar serta bertindak sebagai penentu harga.

2. Posisi tawar petani rumput laut yang rendah sebagai akibat dari adanya ikatan yang kuat dengan pedagang pengumpul yang menjadi langganan tetapnya, dalam hal ini berupa pinjaman modal dan pinjaman biaya hidup sehari-hari, sehingga mengakibatkan petani rumput laut cenderung sebagai penerima harga.

3. Marjin pemasaran pada setiap pola pemasaran diperoleh dengan cara mengurangi harga jual dimasing-masing tingkatan pedagang dengan harga jual ditingkat petani rumput laut. Berdasarkan hasil analisis tersebut diperoleh bahwa semakin banyak jumlah pelaku pemasaran yang terlibat dapat mengakibatkan marjin menjadi lebih besar. Akan tetapi jika dilihat dari segi presentase bagian harga yang diterima petani rumput laut pada tabel tampaknya cukup besar pada masing-masing pola pemasaran.

\subsection{Saran}

Untuk memperbaiki pemasaran rumput laut (Eucheuma cottonii) agar dapat lebih efisien, maka :

1. Petani rumput laut membutuhkan suatu wadah baik dalam bentuk koperasi atau organisasi lain sebagai tempat berkumpul dalam menjalankan kegiatan usaha budidaya rumput laut, sehingga mereka dapat mengatasi permasalahan secara bersama, baik itu input, teknik produksi, pemasaran maupun informasi pasar.

2. Perlu dilakukan sistem pembinaan, penyuluhan, peningkatan kemampuan kerja, serta pelatihan, dengan mengembangkan koordinasi dengan seluruh stakeholder (balai riset dinas terkait, LIPI, Universitas terkait dll).

3. Rumput laut di kota Tual masih didominasi oleh pedagang pengumpul, karena adanya ikatan yang kuat antara petani rumput laut dan pedagang pengumpul dalam peminjaman modal usaha serta peminjaman biaya hidup sehari-hari, sehingga perlu sosialisasi tentang kredit usaha rakyat. Sehingga petani rumput laut dapat melakukan usaha secara mandiri tanpa di pengaruhi oleh pedagang pengumpul.

\section{DAFTAR PUSTAKA}

Anggadiredja, J.T. 2007. Potential and Prospect of Indonesia Seaweed Industry Development. The Indonesia Agency for the Assessment and Application of Technology - Indonesia Seaweed Society. Jakarta.

Anindita, R. 2003. Dasar-dasar Pemasaran Hasil Pertanian. Jurusan Sosial Ekonomi Unibraw Malang.

Firdaus, M., R. Oktaviani., Alla A dan sahara. 2008. Analisis Struktur, Perilaku dan Kinerja Industri Manufaktur di Indonesia. Working Paper. Departemen Ekonomi, Fakultas Ekonomi dan Manajemen. IPB. Bogor.

Joesron, dan Fathorrozi (2003), Teori Ekonomi Mikro. Penerbit Salemba empat, Jakarta.

Nasution, S. 2003. Metode Research (Penelitian Ilmiah). Edisi Pertama. Bumi Aksara. Jakarta.

Nikijuluw. V. P. H, Abarahamsz. J, Dangeubun. F. D. W, 2007. Kajian Data Base Perikanan dan Kelautan Maluku Untuk Kelayakan Investasi. Ambon.

Kohl, Richard L, and J. Uhl. 1985. Marketting of Agricultural Product, $5^{\text {th }}$ Edition. Mc-Millan Publishing and Co-Inc. New York.

Suhendar, S. 2006. Pengembangan Agribisnis Komoditi Rumput Laut Melalui Model Klaster Bisnis, Infokop Nomor 28 Tahun XXII, 2006 Hal 71 - 78.

Sukadi, F. 2007. Pengembangan Budidaya Rumput Laut di Indonesia. Makalah disampaikan pada Seminar Kebijakan Investasi Bidang Pengolahan dan Pemasaran Hasil Perikanan 5 Juli 2007. Ditjen P2HP. DKP.

Wibowo, R. 2004. Koperasi dan Korporasi Petani: Kunci Pembuka Pengembangan Agribisnis Berdaya Saing, Berkerakyatan dan Berkeadilan. Infokop edisi 24 Tahun 2004. 


\section{Lampiran}

Tabel 1. Marjin Pemasaran dan Share Petani Rumput Laut Pola Pertama.

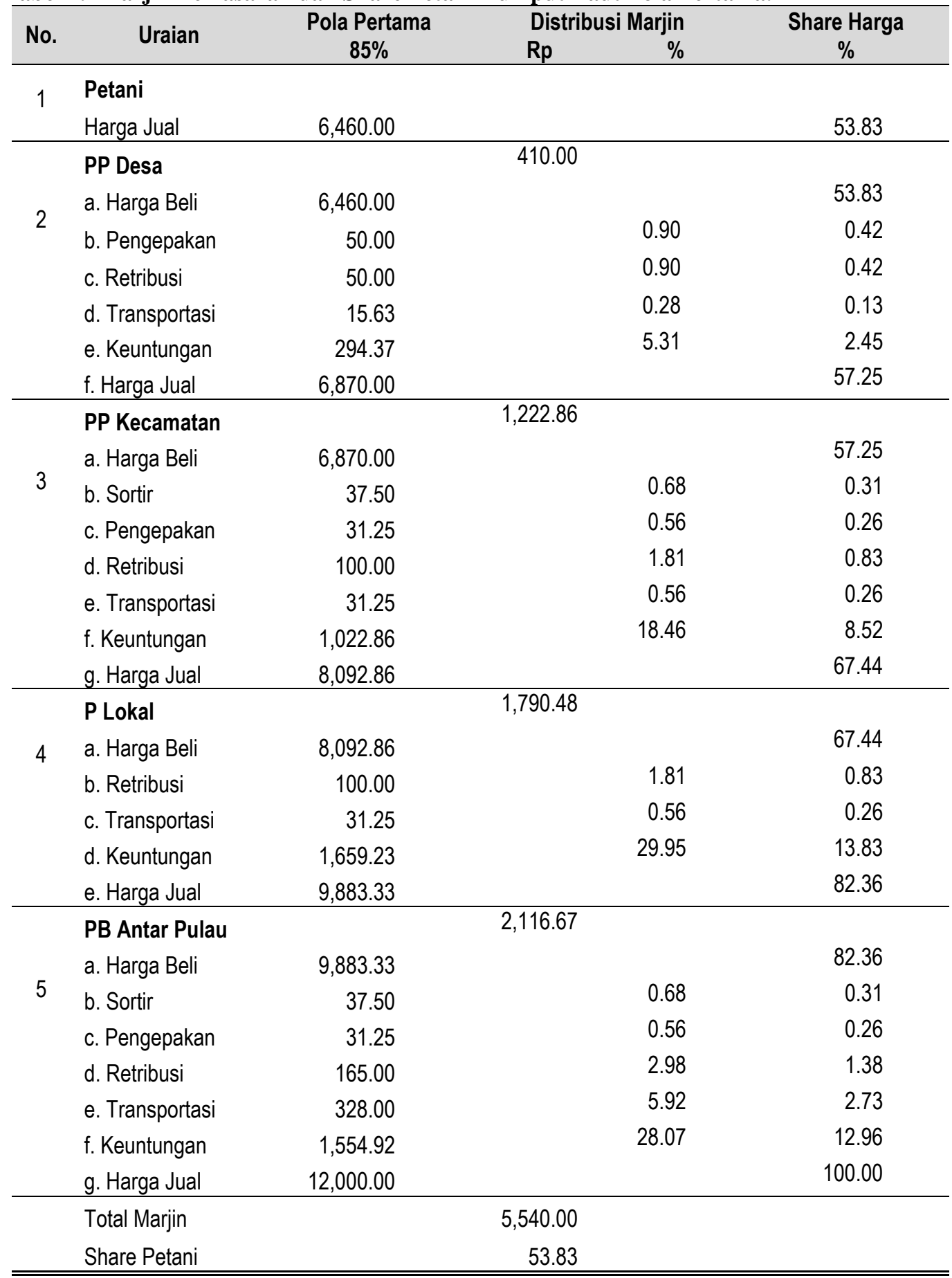


Tabel 2. Marjin Pemasaran dan Share Petani Rumput Laut Pola Kedua.

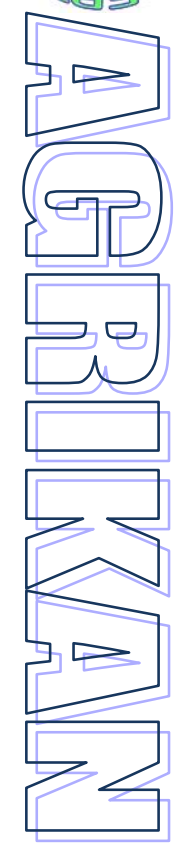

\begin{tabular}{|c|c|c|c|c|}
\hline \multirow{2}{*}{ No } & \multirow{2}{*}{ Uraian } & Pola Kedua & Distribusi Marjin & \multirow{2}{*}{$\begin{array}{c}\text { Share Harga } \\
\%\end{array}$} \\
\hline & & $10 \%$ & $\mathrm{Rp}$ & \\
\hline \multirow{2}{*}{1} & Petani & & & \\
\hline & Harga Jual & $6,870.00$ & & 57.25 \\
\hline
\end{tabular}
2
a. Harga Beli
2 b. Pengepakan
c. Retribusi
d. Transportasi
e. Keuntungan

f. Harga Jual

\begin{tabular}{lrrr}
\hline PP Kecamatan & \multicolumn{3}{c}{$3,013.33$} \\
a. Harga Beli & $6,870.00$ & 0.73 & 57.25 \\
b. Sortir & 37.50 & 0.61 & 0.31 \\
c. Pengepakan & 31.25 & 1.95 & 0.26 \\
d. Retribusi & 100.00 & 0.61 & 0.83 \\
e. Transportasi & 31.25 & 54.84 & 0.26 \\
f. Keuntungan & $2,813.33$ & & 23.44 \\
g. Harga Jual & $9,883.33$ & & 82.36 \\
\hline
\end{tabular}

\section{P Lokal}

4 a. Harga Beli

b. Retribusi

c. Transportasi

d. Keuntungan

e. Harga Jual

PB Antar Pulau

$2,116.67$

$\begin{array}{lrrr}\text { a. Harga Beli } & 9,883.33 & & 82.36 \\ \text { b. Sortir } & 37.50 & 0.73 & 0.31 \\ \text { c. Pengepakan } & 31.25 & 0.61 & 0.26 \\ \text { d. Retribusi } & 165.00 & 3.22 & 1.38 \\ \text { e. Transportasi } & 328.00 & 6.39 & 2.73 \\ \text { f. Keuntungan } & 1,554.92 & 30.31 & 12.96 \\ \text { g. Harga Jual } & 12,000.00 & & 100.00\end{array}$

$\begin{array}{lr}\text { Total Marjin } & 5,130.00 \\ \text { Share Petani } & 57.25\end{array}$


Tabel 3. Marjin Pemasaran dan Share Petani Rumput Laut Pola Ketiga.

\begin{tabular}{|c|c|c|c|c|}
\hline \multirow{2}{*}{ No } & \multirow{2}{*}{ Uraian } & \multirow{2}{*}{$\begin{array}{c}\text { Pola Ketiga } \\
5 \%\end{array}$} & Distribusi Marjin & \multirow{2}{*}{$\begin{array}{c}\text { Share Harge } \\
\%\end{array}$} \\
\hline & & & $\mathrm{Rp}$ & \\
\hline \multirow{2}{*}{1} & Petani & & & \\
\hline & Harga Jual & $8,092.86$ & & 67.44 \\
\hline
\end{tabular}

\section{PP Desa}

2
a. Harga Beli

b. Pengepakan

c. Retribusi

d. Transportasi

e. Keuntungan

f. Harga Jual

\section{PP Kecamatan}
a. Harga Beli

3 b. Sortir

c. Pengepakan

d. Retribusi

e. Transportasi

f. Keuntungan

g. Harga Jual

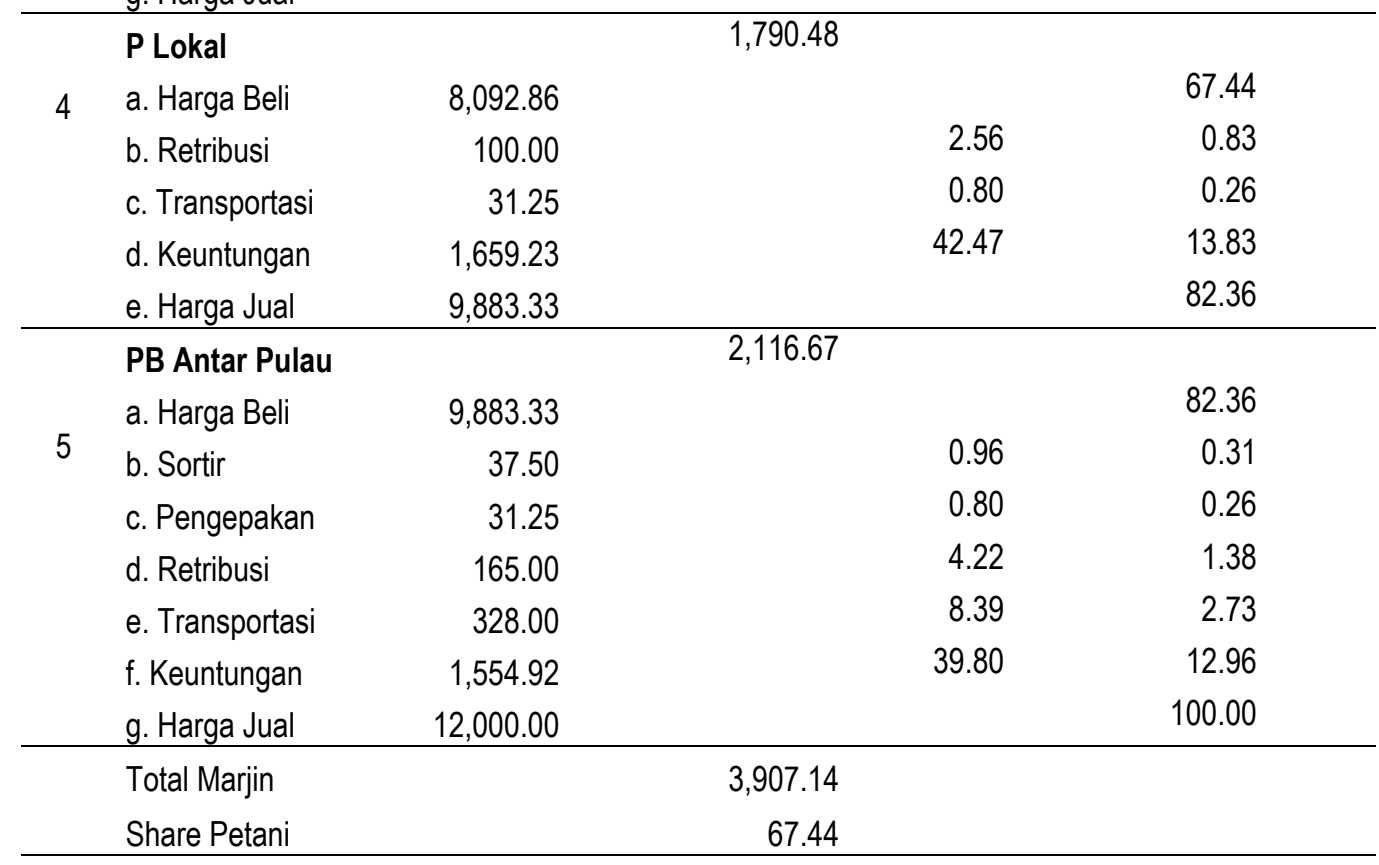

